\title{
Stan dostosowania systemów utrzymania ruchu do warunków Przemystu 4.0
}

\author{
Prof. dr hab. inż. Stefan Trzcieliński iD \\ Politechnika Poznańska, Wydział Inżynierii Zarządzania \\ Instytut Zarządzania i Systemów Informacyjnych
}

\section{Wprowadzenie}

Szeroko rozumiana technologia rozwija się ewolucyjnie z chwilowymi przyspieszeniami, nazywanymi rewolucjami przemysłowymi. Ponad $3 \mathrm{mln}$ lat temu używano narzędzi kamiennych, 4 tys. lat temu wytapiano rudy miedzi i cyny, budowano piramidy i stosowano wozy z pełnymi kołami, w XVIII wieku maszyna parowa zrewolucjonizowała przemysł (I rewolucja przemysłowa), w drugiej połowie XIX wieku umiejętność wytwarzania i akumulowania energii elektrycznej zaowocowała ogromnym wzrostem potencjału produkcyjnego i różnorodnością wyrobów (II rewolucja przemysłowa).

Zastosowanie w latach siedemdziesiątych XX wieku komputerów uważa się za początek III rewolucji przemysłowej. Zaowocowała ona obecnym poziomem technologicznym i dostępnymi produktami. Jej symbolami są automatyzacja i robotyzacja produkcji, a w tym obrabiarki sterowane numerycznie (Numerical Control - NC) i komputerowo (Computer Numerical Control - CNC), roboty przemysłowe, zautomatyzowane ciągi transportowe (Automated Guided Vehicle - AGV), zautomatyzowane magazyny itp. Zarządzanie zakładami wyposażonymi w takie środki produkcji jest wspomagane komputerowo. Powszechnie stosuje się systemy komputerowe wspomagające projektowanie wyrobów (Computer Aided Design - CAD), wytwarzanie (Computer Aided Manufacturing - CAM), projektowanie technologii (Computer Aided Proces Planning - CAPP) oraz ich różne integracje, wspomagające prace inżynieryjne (Computer Aided Engineering - CAE), inżynierię odwrotną (Rewers Engineering - RE), rzeczywistość wirtualną (Virtual Reality - VR), a także systemy wspomagające zarządzanie wszystkimi zasobami (Enterprise Resource Planning - ERP).

$\mathrm{Na}$ osiągnięcia wytwórcze III rewolucji przemysłowej nakładają się rezultaty gwałtownego rozwoju elektroniki, telekomunikacji oraz technologii 
informacyjnych i komunikacyjnych, w tym metody sztucznej inteligencji, przetwarzanie ogromnych zbiorów danych (hurtownie danych, Big Data), maszynowe uczenie się, technologie mobilne i internetowe, Internet rzeczy, a wkrótce Internet wszechrzeczy. Prowadzi to do kolejnej - IV rewolucji technologicznej, nazywanej Przemysłem 4.0 (Industry 4.0).

Wytworzenie narzędzi, maszyn, instalacji, ogólnie infrastruktury technicznej wymaga zużycia zasobów, a więc powoduje koszty. Koszty te z reguły wzrastają wraz ze wzrostem ich skomplikowania. Infrastruktura techniczna zużywa się w trakcie eksploatacji. Proces zużycia następuje szybciej, gdy eksploatacja jest niezgodna $\mathrm{z}$ warunkami, dla których została zaprojektowana. Oprócz stopniowego zużywania się podlega ona nagłym zdarzeniom częściowej bądź całkowitej utraty funkcjonalności, czyli awariom. Zwykle koszt naprawy jest niższy niż koszt jej wytworzenia. Dlatego z ekonomicznego punktu widzenia znaczenia nabiera system utrzymania infrastruktury technicznej w zdolności eksploatacyjnej. Proste i tanie narzędzia, gdy ulegną zużyciu, zastępuje się nowymi. Jednak im infrastruktura, w szczególności maszyny, jest bardziej skomplikowana i droga, tym bardziej ważne jest zapewnienie jej dostępności w cyklu jej życia. Działania zmierzające do tego nazywane są systemem utrzymania ruchu.

System utrzymania ruchu przybiera różne formy. Wiele współczesnych maszyn wyposażonych jest w czujniki i moduły kontrolno-pomiarowe, które zbierają dane o ich stanie. Na podstawie tych danych możliwe jest prognozowanie potrzebnych działań w zakresie utrzymania ruchu, tak aby zapobiec awariom, a przez to zapewnić nieprzerwaną dostępność produkcyjną maszyny. System taki nazywa się predyktywnym utrzymaniem ruchu (predictive maintenance).

Poziom automatyzacji i robotyzacji wzrasta i będzie wzrastać za sprawą osiągnięć w zakresie elektroniki, telekomunikacji i informatyki. W pełni zautomatyzowane systemy produkcyjne, złożone z maszyn komunikujących się między sobą, diagnozujących swój stan i przesyłających dane o nim do centrum sterowania składają się na Przemysł 4.0. Poziom technologiczny tych systemów umożliwia utrzymanie ich w zdolności eksploatacyjnej poprzez wykorzystanie predykcyjnego utrzymania ruchu. Celem tego rozdziału jest sprawdzenie, czy systemy utrzymania ruchu stosowane przez duże i średniej wielkości przedsiębiorstwa działające w Polsce są zbliżone do predyktywnego utrzymania ruchu. Jest to problem ważny i aktualny, gdyż jednym z warunków właściwego funkcjonowania przedsiębiorstwa Przemysłu 4.0 jest wdrożenie tego systemu. Jest to również problem nowy. W bazie Scopus pod hasłem predective maintenance znajduje się tylko pięć pozycji, a po uzupełnieniu go o adjustment, Industry 4.0 Scopus nie zwraca żadnej 
pozycji. W bazie tej pod hasłem predykcyjne utrzymanie ruchu znajdują się tylko dwie polskojęzyczne pozycje i nie są one powiązane z problematyką Przemysłu 4.0.

\section{Systemy utrzymania ruchu}

\section{Reaktywne systemy utrzymania ruchu}

Najprostszym podejściem jest „zepsuło się, to wymień na nowe”. Jest to podejście kosztowne i stosowane wtedy, gdy koszty naprawy przewyższają koszty zakupu nowego sprzętu. W przypadku gospodarstw domowych jest ono często stosowane w odniesieniu do sprzętu elektronicznego. Współcześnie raczej rzadko naprawia się na przykład telewizor, a urządzeń typu MP3 w ogóle się nie naprawia. Podejście to jest również stosowane w przedsiębiorstwach, głównie w odniesieniu do prostych narzędzi - nie naprawia się na przykład pękniętego wiertła.

Kosztowne jest również korekcyjne utrzymanie ruchu (corrective maintenance). Jest to podejście reaktywne, które opiera się na logice „popsuło się, to napraw”. Brak wcześniejszego działania zapobiegawczego może doprowadzić do tego, że niewłaściwie działająca część maszyny może spowodować uszkodzenie innych i w konsekwencji awarię całej maszyny. Ponosi się wtedy nie tylko wysoki koszt jej naprawy, ale również koszty utraconych korzyści w postaci braku produktów.

Oba powyższe podejścia charakteryzują się brakiem działań prewencyjnych. Jak wskazują Muhlemann, Oakland i Lockyer: „istnieje wiele sytuacji, w których najlepszą strategią obsługi jest dopuszczenie do uszkodzenia, zanim przystąpi się do prac remontowych"1. Istnieje bowiem konflikt pomiędzy kosztem działań prewencyjnych i kosztem jednostkowym wyrobu (rysunek 1).

$\mathrm{Z}$ metodycznego punktu widzenia, ale również pod względem historycznym, systemem przejściowym od systemów reaktywnych do proaktywnych jest system remontów planowo-zapobiegawczych. Natomiast w pełni proaktywne są: system proaktywny - prewencyjny (total preventive maintenance), proaktywny - proefektywny (total productive maintenance) oraz system predykcyjny (predective maintenance).

1 A.P. Muhlemann, J.S. Oakland, K.G. Lockyer, Zarzq̨dzanie. Produkcja i usługi, Państwowe Wydawnictwo Naukowe, Warszawa 1992, s. 209. 


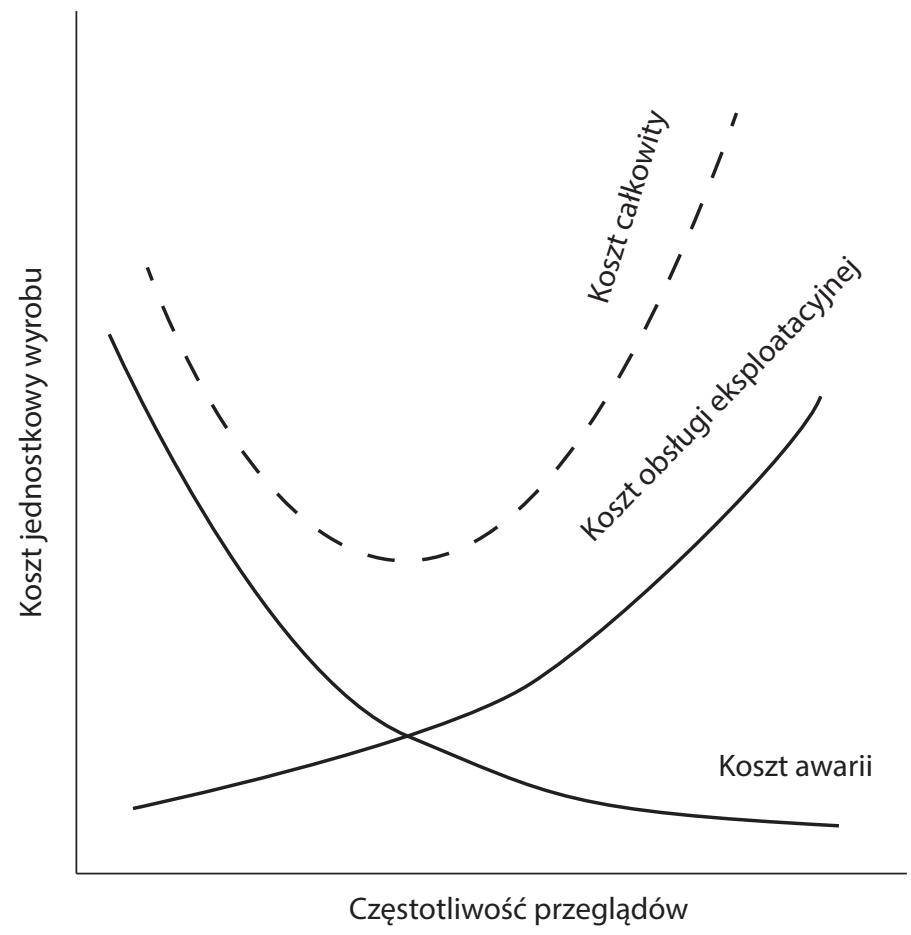

Rysunek 1. Catkowity koszt „strategii” obstugi eksploatacyjnej

Źródto: opracowanie własne na podstawie A.P. Muhlemann, J.S. Oakland, K.G. Lockyer, Zarządzanie. Produkcja i usługi, Państwowe Wydawnictwo Naukowe, Warszawa 1992.

\section{System remontów planowo-zapobiegawczych}

System remontów planowo-zapobiegawczych (planned/scheduled maintenance) jest tradycyjnym podejściem do utrzymania obiektów w zdolności eksploatacyjnej, polegającym na realizacji bieżącej obsługi środków trwałych, okresowych czynności profilaktycznych oraz ich remontów w okresie cyklu remontowego. Jest to okres upływający od momentu oddania obiektu do eksploatacji do pierwszego remontu kapitalnego oraz pomiędzy kolejnymi remontami kapitalnymi ${ }^{2}$. Remont kapitalny obejmuje zakres prac niezbędnych do przywrócenia obiektowi pierwotnej funkcjonalności, przy czym może on obejmować również działania modernizacyjne zwiększające właściwości eksploatacyjne obiektu. Cykl remontowy jest

2 S. Wóycicki, Gospodarka środkami trwatymi, [w:] praca zbiorowa, Zasady organizacji przedsiębiorstwa przemysłowego, Wydawnictwa Naukowo-Techniczne, Warszawa 1974, s. 417-449; S. Lis, Organizacja i ekonomika procesów produkcyjnych w przemyśle maszynowym, Państwowe Wydawnictwo Naukowe, Warszawa 1984. 
wyznaczany albo liczbą godzin eksploatacji obiektu, albo też liczbą wykonanych przez ten obiekt (maszynę) produktów ${ }^{3}$. W okresie cyklu remontowego wykonywane są remonty bieżące i średnie, a pomiędzy remontami realizowane są przeglądy obiektu. W zależności od liczby remontów rozróżnia się cykl dziewięcio-, sześcio- i czteroremontowy.

System remontów planowo-zapobiegawczych może być realizowany za pomocą następujących metod4:

- metoda remontów poprzeglądowych polega na tym, że planuje się tylko terminy przeglądów; przegląd polega na sprawdzaniu stanu technicznego, połączonym z konserwacją, regulacją oraz wymianą lub naprawą drobnych elementów obiektu ${ }^{5}$; w rezultacie możliwa jest ocena stanu technicznego i określenie zakresu i terminów remontów obiektu;

- metoda remontów okresowych polega na planowaniu remontów i przeglądów na podstawie normatywów przyjętych dla danej branży i rodzaju środków trwałych; normatywy te określają cykl remontowy, okresy międzyremontowe, zakres remontów (remonty bieżące i średnie), ich pracochłonność, przestoje remontowe oraz koszt remontów; remonty bieżące obejmują czynności właściwe dla przeglądu oraz naprawę i wymianę mniejszych podzespołów; przyjmuje się, że koszt napraw bieżących może wynosić do $10 \%$ wartości początkowej maszyny ${ }^{6}$; natomiast zakres remontów średnich obejmuje działania właściwe dla remontów bieżących oraz naprawę i wymianę podzespołów, przy czym łączny koszt powinien mieścić się w przedziale od 10 do 30\% wartości nowej maszyny (obiektu);

- metoda remontów normatywnych polega na ścisłym określeniu normatywów dotyczących cyklu remontowego, okresów międzyremontowych, zakresu i pracochłonności remontów, przestojów remontowych oraz kosztów remontów; normatywy te muszą być bezwzględnie przestrzegane, gdyż od tego mogą zależeć warunki bezpieczeństwa eksploatacji obiektów.

Pewną odmianą systemu remontów planowo-zapobiegawczych jest prowadzenie wymiany elementów w okresach dostępności obiektów, na przykład w trakcie letniej przerwy urlopowej. Jest to korzystne zwłaszcza dla instalacji pracujących w systemie ciągłym, ale może spowodować przekroczenie okresu międzyremontowego ${ }^{7}$.

3 A.P. Muhlemann, J.S. Oakland, K.G. Lockyer, Zarzqdzanie...

4 S. Wóycicki, Gospodarka...; S. Lis, Organizacja i ekonomika...

5 L. Pasieczny (red.), Encyklopedia organizacji i zarządzania, Polskie Wydawnictwo Ekonomiczne, Warszawa 1981.

6 Tamże.

7 A.P. Muhlemann, J.S. Oakland, K.G. Lockyer, Zarządzanie... 


\section{System proaktywny - prewencyjny (total preventive maintenance)}

System ten nakierowany jest na zwiększenie niezawodności maszyn i zmniejszenie strat produkcyjnych poprzez wyeliminowanie, a co najmniej ograniczenie zakresu remontów poawaryjnych. W tym celu prowadzi się systematycznie okresowe przeglądy inspekcyjne pod kątem zidentyfikowania zagrożeń i usunięcia drobnych wad, które w rezultacie mogłyby doprowadzić do awarii. Chodzi tutaj o zagrożenia i wady powodowane normalnym zużyciem materiału i jego zmęczeniem, a także niedbalstwem. Przeglądów dokonuje operator maszyny na podstawie listy działań kontrolnych przywieszonych przy maszynie. Operator jest zobowiązany do utrzymania maszyny w czystości (5S), przeprowadzenia konserwacji oraz wykonania drobnych regulacji. Na podstawie listy kontrolnej służby utrzymania ruchu oceniają ryzyko awarii oraz planują niezbędne działania zapobiegawcze.

\section{System proaktywny - kompleksowe utrzymanie ruchu (total productive maintenance)}

Człon „kompleksowe” (total) w nazwie tego systemu oznacza, że w utrzymanie ruchu powinni być włączeni wszyscy pracownicy, poczynając od kierownictwa naczelnego, a kończąc na operatorze maszyny ${ }^{8}$, ale również to, że utrzymanie ruch zostaje zintegrowane $\mathrm{z}$ działaniami produkcyjnymi, w wyniku czego zmniejszone zostają przestoje wynikające z nieterminowych dostaw materiału, przezbrojeń maszyn (SMED) czy niewłaściwej organizacji procesu produkcyjnego ${ }^{9}$.

Podobnie jak w przypadku prewencyjnego utrzymania ruchu kluczową rolę w TPM pełnią operatorzy maszyn, którzy są odpowiedzialni za przeprowadzanie czynności kontrolnych według listy zawieszonej przy maszynie ${ }^{10}$. Pojawia się tutaj jednak jakościowa różnica - TPM zostało opracowane w warunkach wyposażania hal produkcyjnych w maszyny reprezentujące wyższy poziom zaawansowania technologicznego, w tym w maszyny (automaty i roboty) wyposażone w czujniki monitorujące ich stan, w szczególności temperaturę, wibracje i olej. Z jednej strony wspomaga to operatora w dokonywaniu bieżących konserwacji i drobnych

8 S. Nakajima, Introduction to TPM. Total Productive Maintenance, Productivity Press, Portland 1988.

9 S. Legutko, Trendy rozwoju utrzymania ruchu urzqdzeń i maszyn. Development trends in machines operations maintenance, „Eksploatacja i Niezawodność” 2009, nr 2, s. 8-16.

10 S. Piersiala, S. Trzcieliński, Systemy utrzymania ruchu, [w:] L. Pacholski, S. Trzcieliński (red.), Koncepcje zarządzania systemami wytwórczymi, Instytut Inżynierii Zarządzania Politechniki Poznańskiej, Poznań 2005, s. 114-126. 
regulacji, a z drugiej dostarcza centralnym służbom utrzymania ruchu informacje, na podstawie których szacują ryzyko awarii i planują działania zapobiegawcze.

Istotnym wyróżnikiem TPM jest pomiar efektywności wykorzystania maszyn poprzez wskaźnik wykorzystania majątku produkcyjnego (Overall Equipment Effectiveness - OEE), którego niska wartość sugeruje potrzebę wprowadzenia zmian $\mathrm{w}$ organizacji procesu produkcyjnego i utrzymania ruchu.

\section{System proaktywny - predykcyjny (predective maintenance)}

Wraz z rozwojem technologicznym maszyn, ich systemów sterowania oraz systemów teleinformatycznych zaistniały nowe możliwości utrzymania ruchu. Takim nowym systemem jest predykcyjne utrzymanie ruchu. Jest ono nakierowane na poprawę produktywności, jakości produktów oraz efektywności systemów produkcyjnych. W pewnym sensie jest ono wynikiem ewolucji kompleksowego utrzymania ruchu. Jego istotą jest regularny i bieżący monitoring stanu oraz efektywności maszyn i ciągów technologicznych, który dostarcza informacji niezbędnych do zmaksymalizowania okresu pomiędzy naprawami oraz zminimalizowania liczby i kosztów nieplanowanych przestojów spowodowanych awariami maszyn. Monitoringowi podlegają: wibracje, termografia, zjawiska z zakresu trybologii oraz dokonywana jest ocena wizualna ${ }^{11}$.

Dane o bieżącym stanie maszyn pozyskiwane są za pomocą sensorów i przekazywane do sterowników PLC (Programmable Logic Controller), które sterują procesami realizowanymi przez maszyny ${ }^{12}$. Sterownikami z kolei steruje system SCADA (Supervisory Control and Data Acquisition), który wraz z tymi sterownikami oraz interfejsami dla personelu centrum sterowania zakładem składa się na przemysłowy system sterowanie (Industrial Control System - ICS). SCADA dostarcza personelowi centrum sterowania dane, które bezpośrednio mogą być wykorzystane w predykcyjnym utrzymaniu ruchu.

\section{Metodyka badań}

Aby sprawdzić, czy stosowane w praktyce systemy utrzymania ruchu zbliżone są do predyktywnego utrzymania ruchu, przeprowadzono badania empiryczne w 65 przedsiębiorstwach średniej wielkości i 35 dużych firmach na terenie Polski, należących do sektorów:

11 R.K. Mobley, An Introduction to Predictive maintenance, Butterworth Heinemann, Amsterdam 2002.

12 V.F.A. Meyer zu Wickern, Challenges and Reliability of Predictive Maintenance, Rhein-Wall University of Applied Sciences, Faculty of Communication and Environment, Kleve 2019. 
- produkcja artykułów spożywczych;

- produkcja napojów;

- produkcja wyrobów tytoniowych;

- produkcja wyrobów tekstylnych;

- produkcja papieru i wyrobów z papieru;

- poligrafia i reprodukcja zapisanych nośników informacji;

- wytwarzanie i przetwarzanie koksu i produktów rafinacji ropy naftowej;

- produkcja chemikaliów i wyrobów chemicznych;

- produkcja podstawowych substancji farmaceutycznych oraz leków i pozostałych wyrobów farmaceutycznych;

- produkcja wyrobów z gumy i tworzyw sztucznych;

- produkcja wyrobów z pozostałych mineralnych surowców niemetalicznych;

- produkcja metali;

- produkcja metalowych wyrobów gotowych, z wyłączeniem maszyn;

- produkcja komputerów, wyrobów elektronicznych i optycznych;

- produkcja urządzeń elektrycznych;

- produkcja maszyn i urządzeń;

- produkcja pojazdów samochodowych, przyczep i naczep, z wyłączeniem motocykli;

- produkcja pozostałego sprzętu transportowego;

- produkcja mebli.

Dane zebrano za pomocą kwestionariusza wywiadu z pytaniami zamkniętymi, $\mathrm{z}$ wykorzystaniem metody CAPI (Computer-Assisted Telephone Interviewing). Respondentami byli: prezesi bądź właściciele firm, dyrektorzy zarządzający, dyrektorzy techniczni, dyrektorzy/szefowie produkcji, inżynierowie produkcji, wśród których było 13 kobiet i 87 mężczyzn. Na potrzeby tego opracowanie ograniczono się do badań ilościowych, głównie do częstości występowania analizowanych zjawisk.

\section{Wyniki badań}

Aby stwierdzić, czy systemy utrzymania ruchu stosowane przez duże i średniej wielkości przedsiębiorstwa działające w Polsce są zbliżone do predyktywnego utrzymania ruchu właściwego dla rozwiązań technologicznych Przemysłu 4.0, zbadano między innymi:

- Czy występująca w przedsiębiorstwach infrastruktura techniczna odpowiada Przemysłowi 4.0, a w tym:

- jakie występują rodzaje infrastruktury technicznej;

- jaki jest poziom automatyzacji w relacji do pracy ludzkiej; 
- jaka jest polityka zarządu firmy w stosunku do wprowadzania maszyn komunikujących się?

Wyniki tych analiz przedstawiono tabeli 1.

- Czy stosowana w badanych przedsiębiorstwach technologia teleinformatyczna odpowiada Przemysłowi 4.0, a w tym:

- jakie są stosowane systemy teleinformatyczne wspomagające zarządzanie firmą;

- jaka jest polityka zarządu w stosunku do wprowadzania technologii Big Data i Business Intelligence?

Wyniki tych analiz przedstawiono w tabeli 2.

- Jakie systemy utrzymania ruchu są stosowane oraz jaki jest zakres ich stosowania?

Wyniki tego badania przedstawiono w tabeli 3.

Tabela 1. Infrastruktura techniczna przedsiębiorstw

\begin{tabular}{|c|c|c|}
\hline \multirow{2}{*}{ Rodzaje infrastruktury technicznej } & \multicolumn{2}{|c|}{$\begin{array}{c}\text { Częstość występowania } \\
{[\%]}\end{array}$} \\
\hline & Ogółem & $\begin{array}{l}\text { Tylko dany } \\
\text { rodzaj }\end{array}$ \\
\hline Maszyny/urządzenia jednocelowe (nieuniwersalne) & 43 & 7 \\
\hline Maszyny/urządzenia uniwersalne - tradycyjne & 55 & 9 \\
\hline Maszyny/urządzenia sterowane numerycznie lub komputerowo & 71 & 17 \\
\hline Manipulatory & 29 & 0 \\
\hline Roboty & 26 & 0 \\
\hline Brak odpowiedzi & 2 & - \\
\hline Poziom automatyzacji podstawowego procesu produkcyjnego & \multicolumn{2}{|c|}{$\begin{array}{c}\text { Częstość występowania } \\
{[\%]}\end{array}$} \\
\hline Nie występuje automatyzacja/robotyzacja & \multicolumn{2}{|c|}{20} \\
\hline Występuje automatyzacja/robotyzacja, ale praca ludzka dominuje & \multicolumn{2}{|c|}{48} \\
\hline Automatyzacja/robotyzacja są w równowadze z pracą ludzką & \multicolumn{2}{|c|}{19} \\
\hline Występuje praca ludzka, ale dominuje automatyzacja/robotyzacja & \multicolumn{2}{|c|}{13} \\
\hline Proces jest w pełni zautomatyzowany & \multicolumn{2}{|c|}{0} \\
\hline $\begin{array}{l}\text { Polityka zarządu firmy w stosunku do wprowadzania maszyn } \\
\text { komunikujących się }\end{array}$ & \multicolumn{2}{|c|}{$\begin{array}{c}\text { Częstość występowania } \\
{[\%]}\end{array}$} \\
\hline Nie planujemy wprowadzenia takich maszyn & \multicolumn{2}{|c|}{24} \\
\hline Może wprowadzimy w nieokreślonej przyszłości & \multicolumn{2}{|r|}{29} \\
\hline Podjęto decyzję o ich wprowadzeniu w ciągu pięciu lat & \multicolumn{2}{|r|}{10} \\
\hline Podjęto decyzję o ich wprowadzeniu w ciągu dwóch lat & \multicolumn{2}{|r|}{11} \\
\hline Mamy takie maszyny i będziemy zwiększać ich liczbę & \multicolumn{2}{|r|}{22} \\
\hline Brak odpowiedzi & \multicolumn{2}{|r|}{4} \\
\hline
\end{tabular}

Źródło: opracowanie własne. 
Tabela 2. Technologie teleinformatyczne wspomagające zarządzanie

\begin{tabular}{|l|c|}
\hline \multicolumn{1}{|c|}{$\begin{array}{c}\text { Stosowane systemy teleinformatyczne wspomagające zarządzanie } \\
\text { firmą }\end{array}$} & $\begin{array}{c}\text { Częstość występowania } \\
{[\%]}\end{array}$ \\
\hline System komputerowy klasy MRP2 lub ERP & 65 \\
\hline $\begin{array}{l}\text { Technologie mobilne do gromadzenia i przesyłu danych } \\
\text { o procesach produkcji/ustug }\end{array}$ & 27 \\
\hline Business Intelligence & 31 \\
\hline Big Data & 16 \\
\hline Brak odpowiedzi Business Intelligence & 15 \\
\hline Polityka zarządu w stosunku do wprowadzania technologii Big Data & Częstość występowania \\
& {$[\%]$} \\
\hline Nie planujemy wprowadzić & 27 \\
\hline Może wprowadzimy w nieokreślonej przyszłości & 39 \\
\hline Podjęto decyzję o wdrożeniu w ciągu pięciu lat & 7 \\
\hline Podjęto decyzję o wdrożeniu w ciągu dwóch lat & 2 \\
\hline Korzystamy i będziemy korzystać z takiego/takich systemów & 13 \\
\hline Brak odpowiedzi & 10 \\
\hline
\end{tabular}

Źródło: opracowanie własne.

Tabela 3. Systemy utrzymania ruchu

\begin{tabular}{|l|c|}
\hline \multicolumn{1}{|c|}{ Stosowane systemy utrzymania ruchu } & $\begin{array}{c}\text { Częstość występowania } \\
{[\%]}\end{array}$ \\
\hline Reaktywne utrzymanie ruchu & 52 \\
\hline System remontów planowo-zapobiegawczych & 67 \\
\hline \multicolumn{1}{|c|}{ System proaktywny - prewencyjny } & 58 \\
\hline Kompleksowe utrzymanie ruchu (TPM) & 33 \\
\hline Predykcyjne utrzymanie ruchu & 19 \\
\hline Brak odpowiedzi & 2 \\
\hline Zakres stosowania systemu remontów planowo-zapobiegawczych & Częstość występowania \\
& {$[\%]$} \\
\hline Około 100\% maszyn & 13 \\
\hline Około 75\% maszyn & 27 \\
\hline Około 50\% maszyn & 15 \\
\hline Około 25\% maszyn & 10 \\
\hline Brak odpowiedzi & 2 \\
\hline Zakres stosowania systemu proaktywnego - prewencyjnego & Częstość występowania \\
\hline Około 100\% maszyn & {$[\%]$} \\
\hline Około 75\% maszyn & 6 \\
\hline Około 50\% maszyn & 11 \\
\hline Około 25\% maszyn & 11 \\
\hline Brak odpowiedzi & 21 \\
\hline Zakres stosowania kompleksowego utrzymania ruchu TPM & Częstość występowania \\
\hline Około 100\% maszyn & {$[\%]$} \\
\hline
\end{tabular}




\begin{tabular}{|l|c|}
\hline \multicolumn{1}{|c|}{ Stosowane systemy utrzymania ruchu } & $\begin{array}{c}\text { Częstość występowania } \\
{[\%]}\end{array}$ \\
\hline Około 75\% maszyn & 6 \\
\hline Około 50\% maszyn & 9 \\
\hline Około 25\% maszyn & 10 \\
\hline Brak odpowiedzi & 6 \\
\hline \multicolumn{1}{|c|}{ Zakres stosowania predykcyjnego utrzymania ruchu } & $\begin{array}{c}\text { Częstość występowania } \\
{[\%]}\end{array}$ \\
\hline Około 100\% maszyn & 2 \\
\hline Około 75\% maszyn & 2 \\
\hline Około 50\% maszyn & 6 \\
\hline Około 25\% maszyn & 9 \\
\hline Brak odpowiedzi & 0 \\
\hline
\end{tabular}

Źródto: opracowanie własne.

\section{Dyskusja i wnioski}

W badanych przedsiębiorstwach współistnieje różnorodna infrastruktura technologiczna. Tylko 33\% firm stosuje infrastrukturę jednorodną, w tym $9 \%$ tradycyjne maszyny uniwersalne (tabela 1). Aż $90 \%$ przedsiębiorstw ma maszyny należące do co najmniej jednego z następujących rodzajów infrastruktury: maszyny/urządzenia jednocelowe (nieuniwersalne), maszyny/urządzenia sterowane numerycznie lub komputerowo, manipulatory, roboty. Pod tym względem można uznać, że są one na drodze do zostania przedsiębiorstwem Przemysłu 4.0. Jednak przyjmując, że do tej kategorii pretendują firmy, w których procesy zautomatyzowane są co najmniej w równowadze z pracą człowieka, to jest ich $32 \%$, a po nałożeniu warunku, że właściwe dla Przemysłu 4.0 są maszyny komunikujące się, odsetek takich firm spada do $22 \%$, przy czym można się spodziewać, że będzie on wzrastać (tabela 1).

Infrastrukturę informatyczną właściwą dla Przemysłu 4.0 ma 32\% przedsiębiorstw (co najmniej jedna $\mathrm{z}$ następujących technologii: technologie mobilne do gromadzenia i przesyłu danych o procesach produkcji/usług, Business Intelligence, Big Data). Odsetek firm dysponujących tymi technologiami pokazuje tabela 2. Jednak tylko 13\% firm ma infrastrukturę informatyczną i jednocześnie komunikujące się maszyny. Można o nich powiedzieć, że pretendują do miana przedsiębiorstw Przemysłu 4.0.

Różnorodność infrastruktury technicznej (tabela 1) idzie w parze z różnorodnością systemów utrzymania ruchu (tabela 3). Ograniczając dalszą analizę do 13\% firm scharakteryzowanych powyżej, można stwierdzić, że tylko 5\% ogółu firm stosuje predykcyjne utrzymanie ruchu. Należą one do następujących branż: produkcja chemikaliów i wyrobów chemicznych, produkcja podstawowych substancji 
farmaceutycznych oraz leków i pozostałych wyrobów farmaceutycznych, produkcja wyrobów z pozostałych mineralnych surowców niemetalicznych, produkcja komputerów, wyrobów elektronicznych i optycznych, produkcja mebli. Przedsiębiorstwa te co najmniej 75\% swojego asortymentu wyrobów gotowych wytwarzają masowo.

Powyższe analizy prowadzą do wniosku, że 5\% badanych firm można uznać za przedsiębiorstwa Przemysłu 4.0. Dla skrócenia tego określenia wprowadzamy nazwę Przedsiębiorstwa 4.0.

Tabela 3 ukazuje, że dominuje system remontów planowo-zapobiegawczych, a następnie system prewencyjny i reaktywny. Przedsiębiorstwa, w których systemy te są stosowane w stosunku do co najmniej 50\% maszyn, są odległe od miana Przedsiębiorstwa 4.0. Stanowią one 80\% ogółu badanych firm. Pretendentami do tego miana są firmy stosujące kompleksowe utrzymanie ruchu (TPM), ale w stosunku do co najmniej 50\% maszyn. Jest ich niewiele - stanowią 15\% ogółu przedsiębiorstw. Na podstawie powyższego można skonstatować, że systemy utrzymania ruchu stosowane w zdecydowanej większości przedsiębiorstw działających w Polsce w zdecydowanej większości nie są dostosowane do warunków Przemysłu 4.0.

Bibliografia

Legutko S., Trendy rozwoju utrzymania ruchu urządzeń i maszyn. Development trends in machines operations maintenance, „Eksploatacja i Niezawodność” 2009, nr 2, s. 8-16.

Lis S., Organizacja i ekonomika procesów produkcyjnych w przemyśle maszynowym, Państwowe Wydawnictwo Naukowe, Warszawa 1984.

Meyer zu Wickern V.F.A., Challenges and Reliability of Predictive Maintenance, Rhein-Wall University of Applied Sciences, Faculty of Communication and Environment, Kleve 2019.

Mobley R.K., An Introduction to Predictive maintenance, Butterworth Heinemann, Amsterdam 2002.

Muhlemann A.P., Oakland J.S., Lockyer K.G., Zarzq̨dzanie. Produkcja i usługi, Państwowe Wydawnictwo Naukowe, Warszawa 1992.

Nakajima S., Introduction to TPM. Total Productive Maintenance, Productivity Press, Portland 1988.

Pasieczny L. (red.), Encyklopedia organizacji i zarządzania, Polskie Wydawnictwo Ekonomiczne, Warszawa, 1981.

Piersiala S., Trzcieliński S., Systemy utrzymania ruchu, [w:] L. Pacholski, S. Trzcieliński (red.), Koncepcje zarzq̨dzania systemami wytwórczymi, Instytut Inżynierii Zarządzania Politechniki Poznańskiej, Poznań 2005, s. 114-126.

Wóycicki S., Gospodarka środkami trwatymi, [w:] praca zbiorowa, Zasady organizacji przedsiębiorstwa przemysłowego, Wydawnictwa Naukowo-Techniczne, Warszawa 1974, s. 417-449. 


\section{Streszczenie}

Idea Przemysłu 4.0 znana jest od 2011 roku. Aktualnie jest ona konkretyzowana przez właściwe dla niej technologie dotyczące automatyzacji i wymiany danych w łańcuchach wartości. Utrzymanie w zdolności eksploatacyjnej tych technologii stawia nowe wyzwania w zakresie dostosowania do warunków Przemysłu 4.0 systemów stosowanych przez służby utrzymania ruchu. Celem tego opracowania jest sprawdzenie, czy systemy i praktyki utrzymania ruchu stosowane w przedsiębiorstwach działających w Polsce są zbliżone do prewencyjnego utrzymania ruchu, które jest uznawane za właściwe dla Przemysłu 4.0. Aby osiągnąć ten cel, przeprowadzono badania empiryczne na próbie stu średnich i dużych przedsiębiorstwach działających w Polsce, dotyczące ich dostosowania do warunków Przemysłu 4.0. Dane pozyskano za pomocą kwestionariusza wywiadu, przy czym respondentami byli menedżerowie służb produkcyjnych i technicznych. Uzyskane wyniki pozwoliły rozpoznać lukę w wiedzy o Przemyśle 4.0 i właściwych dla niego praktykach utrzymania ruchu. Mogą być one podstawą do kształtowania programów podnoszących w tym zakresie wiedzę i kompetencje kadr przedsiębiorstw wchodzących na ścieżkę Przemysłu 4.0 i znajdujących się na niej.

Słowa kluczowe: utrzymanie ruchu, Przemysł 4.0, automatyzacja i robotyzacja, prewencyjne utrzymanie ruchu, predykcyjne utrzymanie ruchu

The current state of adjustment of maintenance systems to the conditions of Industry 4.0

\section{Abstract}

The Idea of Industry 4.0 has been known since 2011. It is currently being developed by its specific technologies regarding automation and data exchange in value chain. To maintain of these technologies in readiness for their exploitation creates a new challenge in terms of adapting systems used by maintenance departments to the conditions of Industry 4.0. The purpose of this article is to check to what extent maintenance systems and practices used in enterprises operating in Poland are close to preventive maintenance, which is considered appropriate for Industry 4.0. To achieve this goal, empirical research was conducted on a sample of 100 medium and large enterprises operating in Poland, regarding the adaptation of these enterprises to the conditions of Industry 4.0. Data was obtained by means of an interview questionnaire, with respondents being managers of production and engineering departments. The obtained results allowed recognizing the gap in knowledge about Industry 4.0 and its proper maintenance practices. They can be the basis for shaping programs raising the knowledge and competences of the personnel of enterprises entering and on the path of Industry 4.0 in this respect.

Keywords: maintenance, Industry 4.0, automation and robotics, preventive maintenance, predictive maintenance 